\title{
Peningkatan Kemampuan Mengenal Huruf Pada Anak Usia 5-6 Tahun Melalui Metode Bermain Dengan Media Kotak Pintar
}

\author{
Sheila Septiana Rahayuningsih, Tritjahjo Danny Soesilo, Mozes Kurniawan \\ sheila.septiana81@gmail.com, tritjahjo.danny@staff.uksw.edu, mozes.kurniawan@staff.uksw.edu \\ PG-PAUD, Fakultas Keguruan dan Ilmu Pendidikan, Universitas Kristen Satya Wacana

\begin{abstract}
Improving The Ability Of Letters Recognizing By Children Aged 5 To 6 Years Old Through Playing
\end{abstract} \\ Method With A 'Smart Box'Media
}

\begin{abstract}
This study aims to improve the ability to recognize letters through the method of playing with the smart box media for children aged 5-6 years in Sion Blora Kindergarten. The activities to identify letters using the smart box media is able to motivate children's interest to learn. This classroom action research was conducted in two cycles with three meetings in each cycle. The subjects of the study were 14 children aged 5-6 years. The data collection was done with interviews, observation, and documentation. The research instrument referred to Permendikbud (Regulation by the Minister of Education and Culture) Number 146 Year 2014. The observation was done with the assessment sheets, documentation, and interviews with the classroom teachers to determine the conditions and problems of children in the classroom, analyzed with a descriptive quantitative technique. The success indicator of this research is $90 \%$ for the average value. The results showed an increase in the average score from the precycle of 14,29\% to 60,71\% in cycle I; up to $92.86 \%$ in cycle II. Thus, it can be said that the percentage of success reached $\geq 90 \%$.
\end{abstract}

Keywords: Ability To Recognize Letters Of 5-6 Years Old, Playing Method, Smart Boxes Media

\section{Article Info}

Received date: 1 Agustus 2018

Revised date: 6 Januari 2019

Accepted date: 22 Januari 2019

\section{PENDAHULUAN}

Anak pada jenjang usia 0-6 tahun merupakan masa pendidikan yang fundamental karena perkembangan anak dimasa selanjutnya sangat ditentukan oleh berbagai stimulus yang diberikan sejak usia dini. Dalam Permendikbud 146 tahun 2014 tentang Kurikulum Pendidikan Anak Usia Dini, dinyatatakan bahwa anak dapat berkembang secara optimal perlu diperhatikan aspek-aspek seperti agama-moral, fisik-motorik, sosial-emosional, kognitf, bahasa dan seni dalam mengembangkan aspek ini harus sesuai dengan kurikulum untuk anak usia dini yaitu dalam konteks bermain. Terkait perkembangan anak dalam sisi bahasa menurut Otto (2015:17) perkembangan bahasa anak ada dua yaitu bahasa lisan dan bahasa tulis. Bahasa lisan merupakan penyampaian informasi secara lisan atau langsung sedangkan tulis merupakan cara penyampaian informasi secara tertulis. Menurut Cochrane Efal dalam Mislahusnika, (2016:15) tahap perkembangan membaca seorang anak antara lain tahap fantasi (magic stage), tahap pembentukan konsep diri (self concept stage), tahap membaca gambar (bridging reading stage), tahap pengenalan bacaan (take-off reader stage), dan tahap membaca lancar (independen reader stage). Berdasarkan tahapan tersebut anak usia 5-6 tahun seharusnya sudah bisa membaca gambar karena pada Permendikbud 146 Tahun 2014 yaitu anak mampu menunjukan keaksaraan awal dengan menunjukan bentuk-bentuk simbol (pra menulis) dan dapat membuat berbagai bentuk karya seperti membuat gambar dengan beberapa coretan atau tulisan yang sudah berbentuk huruf atau kata.

Berdasarkan hasil wawancara dengan guru kelas di TK Sion Blora diperoleh informasi bahwa "terdapat 12 anak dari 14 anak usia 5-6 tahun belum bisa mengenal huruf dengan benar". Tidak hanya dengan wawancara namun peneliti juga melakukan observasi di TK Sion Blora. Observasi dilaksanakan pada saat pembelajaran dengan tema buah. Guru menggambarkan buah-buahan beserta namanya di papan tulis kemudian anak-anak menirukan gambar dan tulisan tersebut di buku masing- 
masing. Pada kegiatan ini ternyata penulis menemukan 2 anak dapat menggambar buah dan menuliskan nama buah dengan benar sedangkan 12 anak lainnya belum bisa, dari 12 anak tersebut 3 di antaranya belum dapat menuliskan sedangkan 9 anak lainnya bisa menuliskan namun masih ada huruf yang hilang dan huruf yang terbalik-balik.

Permasalahan dalam pembelajaran mengenal huruf di TK Sion Blora adalah masih digunakannya cara-cara lama yang kurang efektif dan penggunaan media yang masih kurang. Proses ini terlihat dari pengenalan huruf dari majalah (lembar kerja anak) dan juga papan tulis dan spidol. Oleh karena itu peneliti akan menggunakan metode bermain dengan kotak pintar sebagai media untuk meningkatkan kemampuan mengenal huruf.

Penelitian ini bertujuan untuk meningkatkan kemampuan mengenal huruf melalui metode bermain dengan media kotak pintar pada anak usia 5-6 tahun di TK Sion Blora.

Manfaat yang diharapkan dalam penelitian ini 1) Manfaat Teoretis: menambah wawasan pengetahuan di bidang pendidikan anak usia dini terutama untuk meningkatkan perkembangan aspek kognitif dan bahasa terlebih kemampuan mengenal huruf anak usia 5-6 tahun melalui metode bermain dengan media kotak pintar. 2) Manfaat Praktis a) bagi siswa: Kemampuan mengenal huruf anak usia 5-6 tahun semakin meningkat melalui metode bermain dengan media kotak pintar. b) bagi guru: Guru dapat berinovasi mengembangkan metode pembelajaran dengan media yang bervariasi. c) bagi peneliti selanjutnya: Dapat menggunakan metode dan media yang lain untuk meningkatkan kemampuan mengenal huruf.

\section{KAJIAN PUSTAKA}

Kemampuan mengenal huruf, menurut Carol Seefelt dan Barbara A. Wasik dalam Trisnawati, (2014:13) adalah kesanggupan melakukan sesuatu dengan mengenali tanda-tanda atau ciri-ciri dari tanda aksara dalam tata tulis yang merupakan anggota abjad yang melambangkan bunyi bahasa. Bromley dalam Sari, (2014:29) mengungkapkan bahwa bahasa sebagai simbol yang teratur untuk memberikan ide maupun informasi yang terdiri dari simbol-simbol visual maupun verbal. Sedangkan menurut Papalia dalam Sari, (2014:30) fungsi simbolis (simbolic function) adalah kemampuan menggunakan simbol, atau representasi mental-kata, angka, atau gambar tempat seseorang melekatkan makna. Pengenalan huruf sejak usia TK adalah hal yang paling penting pengajarannya harus melalui proses sosialisasi, dan metode pengajaran membaca tanpa membebani dan dengan kegiatan belajar yang menyenangkan (Hasan, 2009:66). Dalam permendikbud 146 tahun 2014 anak usia 5-6 tahun sudah dapat menguasai indikator mengenal keaksaraan awal: a) menunjukkan bentukbentuk simbol (pra menulis), b) membuat gambar dengan beberapa coretan atau tulisan yang sudah berbentuk huruf atau kata, c) menulis huruf-huruf dari namanya sendiri. Setiap satuan pendidikan formal dan non formal menyediakan sarana dan prasarana yang memenuhi keperluan pendidikan sesuai dengan pertumbuhan dan perkembangan potensi fisik, kecerdasan intelektual, sosial emosional serta kejiwaan peserta didik ( kusumawati, 2017:17).

Seefelt dan Barbara A. Wasik (2008:375) mengatakan bahwa membaca merupakan keterampilan berbahasa yang merupakan proses bersifat fisik dan psikologis. Keterampilan yang dikembangkan adalah huruf cetak. Mereka mempunyai kesempatan untuk berinteraksi dengan huruf cetak. Belajar mengenal huruf untuk mencapai kemampuan membaca awal bagi anak-anak.

Sedangkan metode bermain menurut Suyadi \& Maulidya dalam Zaini, (2015:122) metode bermain merupakan bentuk Pendidikan untuk anak usia dini yang menggunakan strategi atau bahan media yang menarik dan dapat diikuti anak secara menyenangkan. Fungsi bermain bagi anak usia dini menurut Conny R. Semiawan dalam Zaini, (2015:120) antara lain: a) meningkatkan aspek-aspek perkembangan, b) anak dapat bereksplorasi, c) anak dapat mengembangkan potensinya secara optimal.

Fungsi bermain bagi anak usia dini menurut Conny R. Semiawan dalam Zaini, (2015:120) antara lain: 1).Meningkatkan aspek-aspek perkembangan. 2).Anak dapat bereksplorasi. 3).Anak dapat mengembangkan potensinya secara optimal.

Jenis bermain bagi anak usia dini menurut Mulyasa dalam Zaini, (2015:122) antara lain: a). Bermain Sosial, bermain sosial merupakan kegiatan bermain yang melibatkan semua anak yang menunjukan derajat partisipasi berbeda. b). Bermain dengan benda, bermain dengan benda merupakan kegiatan bermain anak ketika mengunakan atau mempermainkan benda-benda tertentu dan dapat 
menjadikan hiburan yang menyenangkan bagi anak. c). Bermain peran, bermain peran merupakan permainan anak yang dihadapkan pada keadaan atau kondisi yang berkaitan dengan bidang pengembangan maupun menyangkut hubungan sosial. Melalui bermain peran anak-anak mencoba untuk bereksplorasi dengan memperagakan dan mendiskusikan hubungan antar manusia sehingga secara tidak langsung dapat mengeksplorasi perasaan, sikap, dan berbagai strategi pemecahaan masalah.

\section{Media Kotak Pintar}

Menurut Arif S. Sadiman (Sadiman1993:11), media merupakan segala sesuatu yang dapat digunakan untuk menyalurkan pesan dari pengirim ke penerima sehingga dapat menyampaikan fikiran, perasaan, perhatian, dan minat serta perhatian siswa sehingga proses belajar terjadi. Sedangkan yang dimaksud dengan kotak pintar Menurut Puspitasari dkk (2013:16) kotak pintar adalah bentuknya balok yang memiliki 2 sisi di dalamnya dan terdapat kartu didalamnya. Kartu tersebut merupakan kartu bergambar dan kartu kata. Menurut Harnanto (2016:35) kotak pintar merupakan suatu kotak kecil yang di dalamnya terdapat alat digunakan untuk belajar. dari kedua paparan tersebut dapat disimpulkan bahwa media kotak pintar merupakan media atau alat yang digunakan untuk menyampaikan informasi yang memeliki bentuk persegi dengan dua bagian atau dua tempat didalamnya yang berisikan huruf dan gambar. Media ini dapat dimainkan dengan cara pertama kali anak mengambil satu gambar yang ada di dalam kotak pintar secara acak lalu pada gambar bertulisakan nama gambar tersebut dam anak mulai mencari atau merangkai huruf sesuai yang ada pada gambar. Contoh yang diambil gambar buah mangga, pada gambar buah mangga bagian bawah bertuliskan M-A-N-G-G-A lalu anak mencari huruf sesuai tulisan.

Adapun manfaat kotak pintar menurut Harnanto (2016:35) adalah meningkatkan daya konsentrasi anak, meningkatkan kekreativitasan anak, meningkatakan hasil belajar siswa, menciptakan suasana menyenangkan saat belajar

Adapun langkah-langkah dalam permainan kotak pintar untuk mengenalkan huruf pada anak usia 5-6 tahun antara lain: a).Menyiapkan media kotak pintar yang terbuat dari kadus dan didalammya terdapat dua sisi yang diisi dengan kartu bergambar buah dilengkapi dengan nama buah tersebut dan kartu kata nama-nama buah. b).Dalam permainan ini anak-anak dibagi menjadi 3 kelompok, setiap kelompok berisi 5 anak. Setiap anak bermain secara bergantian. c).Dalam permainan ini setiap anak harus mampu mencari kartu yang bergambar buah dengan kartu kata nama buah (contoh) tersebut setelah itu anak menuliskan nama buah tersebut di lembar kertas masing-masing yang sudah disedikan guru.

Berikut beberapa Hasil penelitian yang relevan dari Waraningsih (2014:83) yang berjudul “ Upaya Meningkatkan Mengenal Huruf Menggunakan Media Kartu Kata Di TK Sulthoni Ngaglik Sleman", mengatakan bahwa kegiatan yang dilakukan di TK tersebut dengan menggunakan media kartu kata dapat meningkatkan pengenalan huruf anak. Trisniwati (2014:51) yang berjudul "Peningkatan Kemampuan Mengenal Huruf Melalui Metode Permainan Kartu Huruf Pada Kelompok B1 TK Aba Ketanggungan WirobrajanYogyakarta ", mengatakan bahwa permainan kartu huruf dapat meningkatkan pengenalan huruf di TK tersebut. Kenthi Puspitasari (2013:50) yang berjudul "Upaya Meningkatkan Kemampuan Mengenal Lambang Bilangan 1-10 Melalui Media Kotak Pintar Pada Anak Kelompok A Tk Pertiwi 1 Balongbesuk Kec. Diwek Kab. Jombang ”, menemukan bahwa dengan kotak pintar kemampuan mengenal lambang 1-10 di sekolah tersebut mengalami peningkatan. Sugeng Harnanto (2016:38) yang berjudul "Alat Peraga Kotak Belajar Ajaib (Kobela) Dalam Pembelajaran Matematika Materi Perkalian Dan Pembagian Sekolah Dasar", mengatakan bahwa alat peraga kotak ajaib dapat meningkatkan atau mengoptimalkan hasil belajar siswa di sekolah dasar.

\section{Kerangka Pikir}

Berdasarkan kajian pustaka dan penelitian yang relevan maka kerangka berpikir yang digunakan dalam penelitian ini adalah : Jika tanpa tindakan apapun dari guru kemampuan anak dalam mengenal konsep huruf dan suku kata sangat rendah, maka peneliti menduga bahwa melalui metode bermain dengan media permainan kotak pintar maka kemampuan anak dalam mengenal huruf dan suku kata akan meningkat. 


\section{METODE}

Jenis penelitian ini adalah penelitian tindakan kelas (Classroom Action Researc). Arikunto (2010:7) mengatakan bahwa penelitian tindakan kelas adalah suatu proses pencermatan terhadap kegiatan belajar berupa sebuah tindakan yang sengaja diadakan dan terjadi di dalam kelas secara bersamaan yang dirancang menggunakan siklus. Dalam satu siklus terdiri dari 4 langkah yaitu : Perencanaan (Planning), Tindakan (Action), Pengamatan (Observing), Refleksi (Reflecting). Subjek penelitian ini adalah 14 anak usia 5-6 tahun TK Sion Blora terletak di Jalan Tentara Pelajar no. 9 Blora, Jawa Tengah.

Variabel penelitian ini dibagi menjadi dua yaitu variabel bebas dan variabel terikat. Variabel bebas dari penelitian ini adalah metode bermain dengan media kotak pintar, sedangkan variabel terikatnya adalah kemampuan mengenal huruf.

Tabel 1. Kisi-Kisi Pedoman Observasi Berdasarkan Permendikbud No. 146 Tahun 2014

\begin{tabular}{|c|c|}
\hline Variabel & Indikator \\
\hline Mengenalkan & 1. Menunjukan bentuk-bentuk simbol (pra menulis) \\
\hline \multirow[t]{3}{*}{ keaksaraan awal } & 2. Membuat gambar dengan beberapa coretan/tulisan yang sudah berbentuk huruf/kata \\
\hline & 3. Menulis huruf-huruf dari namanya sendiri \\
\hline & 4. Mencocokan huruf dengan gambar \\
\hline
\end{tabular}

Table 2. Pedoman Penilaian Observasi Mengenal Simbol Huruf

\begin{tabular}{|c|c|c|c|c|c|}
\hline \multirow[b]{2}{*}{$\begin{array}{c}\text { Kompetensi } \\
\text { Dasar }\end{array}$} & \multirow[b]{2}{*}{ Indikator } & \multicolumn{4}{|c|}{ Kategori } \\
\hline & & $\begin{array}{c}\text { Baik } \\
(4)\end{array}$ & $\begin{array}{c}\text { Cukup } \\
\text { (3) }\end{array}$ & $\begin{array}{c}\text { Kurang } \\
(2)\end{array}$ & $\begin{array}{c}\text { Sangat Kurang } \\
\text { (1) }\end{array}$ \\
\hline \multirow{4}{*}{$\begin{array}{l}3.12 \text { Mengenal } \\
\text { keaksaraan awal } \\
4.12 \\
\text { Menunjukan } \\
\text { kemampuan } \\
\text { keaksaraan awal } \\
\text { dalam berbagai } \\
\text { bentuk karya }\end{array}$} & $\begin{array}{l}\text { 1. Menunjuka } \\
\mathrm{n} \text { bentuk- } \\
\text { bentuk } \\
\text { simbol (pra } \\
\text { menulis) }\end{array}$ & $\begin{array}{l}\text { mampu } \\
\text { menunjukan } \\
21-26 \text { huruf }\end{array}$ & $\begin{array}{l}\text { mampu } \\
\text { menunjukan } 15- \\
20 \text { huruf }\end{array}$ & $\begin{array}{l}\text { mampu } \\
\text { menunjukan } 7- \\
14 \text { huruf }\end{array}$ & $\begin{array}{l}\text { mampu } \\
\text { menunjukan } 1-6 \\
\text { huruf }\end{array}$ \\
\hline & $\begin{array}{l}\text { 2. Membuat } \\
\text { gambar } \\
\text { dengan } \\
\text { berbagai } \\
\text { coretan/tuli } \\
\text { san yang } \\
\text { sudah } \\
\text { berbentuk } \\
\text { huruf/kata }\end{array}$ & $\begin{array}{l}\text { mampu } \\
\text { menuliskan } \\
\text { beberapa } \\
\text { huruf yang } \\
\text { membentuk } \\
\text { satu kata } \\
\text { dengan } \\
\text { benar }\end{array}$ & $\begin{array}{l}\text { mampu } \\
\text { menuliskan } \\
\text { beberapa huruf } \\
\text { menjadi satu } \\
\text { kata meskipun } \\
\text { masih ada huruf } \\
\text { yang terbalik }\end{array}$ & $\begin{array}{l}\text { mampu } \\
\text { menuliskan } \\
\text { suku kata } \\
\text { pertama }\end{array}$ & $\begin{array}{l}\text { Mampu } \\
\text { menuliskan huruf } \\
\text { depan dari suatu } \\
\text { kata }\end{array}$ \\
\hline & $\begin{array}{l}\text { 3. Menulis } \\
\text { huruf- } \\
\text { huruf dari } \\
\text { namanya } \\
\text { sendiri }\end{array}$ & $\begin{array}{l}\text { mampu } \\
\text { menulisakan } \\
\text { namanya } \\
\text { dengan } \\
\text { benar }\end{array}$ & $\begin{array}{l}\text { mampu } \\
\text { menuliskan } \\
\text { namanya } \\
\text { meskipun } \\
\text { dengan huruf } \\
\text { yang terbalik }\end{array}$ & $\begin{array}{l}\text { mampu } \\
\text { menuliskan } \\
\text { namanya } \\
\text { meskipun ada } \\
\text { beberapa huruf } \\
\text { hilang }\end{array}$ & $\begin{array}{l}\text { belum mampu } \\
\text { menuliskan } \\
\text { namanya sendiri }\end{array}$ \\
\hline & $\begin{array}{l}\text { 4. Mencocoka } \\
\mathrm{n} \quad \text { huruf } \\
\text { dengan } \\
\text { gambar }\end{array}$ & $\begin{array}{l}\text { mampu } \\
\text { mencocokan } \\
\text { huruf } \\
\text { dengan } \\
\text { benar }\end{array}$ & $\begin{array}{l}\text { mampu } \\
\text { mencocokan } \\
\text { huruf dengan } \\
\text { gambar namun } \\
\text { masih terbalik }\end{array}$ & $\begin{array}{l}\text { mampu } \\
\text { mencocokan } \\
\text { huruf dengan } \\
\text { gambar namun } \\
\text { belum mengerti } \\
\text { nama huruf }\end{array}$ & $\begin{array}{l}\text { belum mampu } \\
\text { mencocokan } \\
\text { huruf dengan } \\
\text { gambar }\end{array}$ \\
\hline
\end{tabular}

\section{Indikator Keberhasilan}

Dalam penelitian ini dikatakan berhasil jika $90 \%$ kemampuan anak dalam mengenal huruf meningkat melalui permainan kotak pintar. Hal ini dapat dilihat dari persentase pencapaian pada semua indikator yang tertera dalam instrumen penelitian. 


\section{HASIL DAN PEMBAHASAN}

\section{Hasil Penelitian}

Kondisi akhir dalam pembelajaran ini adalah meningkatnya kemampuan keaksaraan awal yaitu kemampuan mengenal huruf yang melalui tindakan dalam dua siklus dalam hasil akhir penggunaan metode bermain dengan media kotak pintar dapat meningkatkan kemampuan mengenal huruf pada anak usia 5-6 tahun di TK Sion Blora

Hasil belajar didapat setelah anak mengalami proses belajar. Dalam penelitian tindakan kelas ini hasil belajar anak usia 5-6 tahun di TK Sion Blora dilihat setelah dilakukan pembelajaran pengenalan huruf dengan media kotak pintar. Ketuntasan perolehan nilai diukur menggunakan hasil observasi dengan indikator kriteria kinerja 1) Kriteria baik, yaitu apabila hasil penilaian kemampuan mengenal huruf yang diperoleh anak antara $76-100 \%, 2$ ) Kriteria cukup, yaitu apabila hasil penilaian kemampuan mengenal huruf yang diperoleh anak antara 56-75\%, 3) Kriteria kurang, yaitu apabila hasil penilaian kemampuan mengenal huruf yang diperoleh anak antara 41-55\%. 4) Kriteria sangat kurang, yaitu apabila hasil penilaian kemampuan mengenal huruf yang diperoleh anak antara 0-40\%. Dalam penelitian ini dikatakan berhasil jika 90\% kemampuan anak dalam mengenal huruf meningkat melalui permainan kotak pintar

Dalam penelitian ini terdapat teknik analisis data yaitu setiap data yang diperoleh dari hasil observasi akan dianalisis. Data yang diperoleh dalam penelitian ini adalah mengenai kemampuan mengenal huruf, analisis data menggunakan metode deskriptif. Hasil kegiatan dianalisis dengan teknik analisis deskriptif kuantitatif yaitu dilakuakan dengan membandingkan hasil tindakan dari suatu siklus dengan kriteria keberhasilan yang ditentukan menurut Soesilo (2014). Analisis yang dilakukan secara deskriptif kuantitatif bertujuan untuk mengetahui peningkatan kemampuan menghafal huruf dalam kegiatan bermain dengan media kotak pintar yang telah terjadi dari awal pembelajaran/tindakan dilakukan sampai siklus akhir. Adapun rumus yang digunakan menurut Anas Sudjono (dalam Waraningsih 2014:35) sebagai berikut:

$$
P=\frac{F}{N} \times 100 \% \quad \begin{aligned}
& \text { Keterangan : } \\
& \mathrm{F}=\text { frekuensi yang sedang dicari persentasenya } \\
& \mathrm{P}=\text { angka of class (jumlah frekuensi) }
\end{aligned}
$$

Berdasarkan observasi tahap awal atau pra tindakan terdapat 14 anak yang menjadi subjek penelitian kemampuan mengenal huruf yang meliputi empat indikator menunjukan masih banyak anak yang belum memenuhi di kategori baik dalam kemampuan mengenal huruf. Rata-rata kemampuan mengenal huruf pada pra siklus didapatkan 14,29\% atau 2 anak dalam kategori baik sedangkan $85,71 \%$ atau 12 anak lainnya masih memerlukan bantuan. Keadaan demikian dijadikan sebuah alasan diadakannya tindakan untuk meningkatakan kemampuan mengenal huruf melalui bermain kotak pintar.

Dalam pelaksanaan tindakan dilakukan dalam dua siklus yang tiap siklusnya terdapat tiga kali tindakan. Hasil pengenalan huruf anak usia 5-6 tahun dengan media kotak pintar pada siklus pertama dapat dilihat melalui tabel berikut ini.

Tabel 3. Hasil Observasi Kemampuan Mengenal Huruf Dalam Kategori Baik Di Siklus I

\begin{tabular}{lccc}
\hline & \multicolumn{3}{c}{ Siklus I } \\
\hline \multirow{2}{*}{ Presentase (\%) } & Pertemuan 1 & Pertemuan 2 & Pertemuan 3 \\
\cline { 2 - 4 } & 30,36 & 44,64 & 60,71 \\
\hline
\end{tabular}

Berdasarkan tabel 1 dapat diketahui tingkat pencapain mengenal huruf di siklus I pada pertemuan pertama menunjukan bahwa 30,36\% anak tergolong pada kategori baik sedangkan pada pertemuan kedua menunjukan $44,64 \%$ anak dalam kategori baik dan pada pertemuan ketiga terdapat $60,71 \%$ anak tergolong dalam kondisi baik. Dalam siklus I ini terdapat tiga kali pertemuan dengan setiap pertemuannya mengalami peningkatan. Berikut ini gambar peningkatan kemampuan mengenalkan huruf dalam bentuk grafik disetiap pertemuan: 


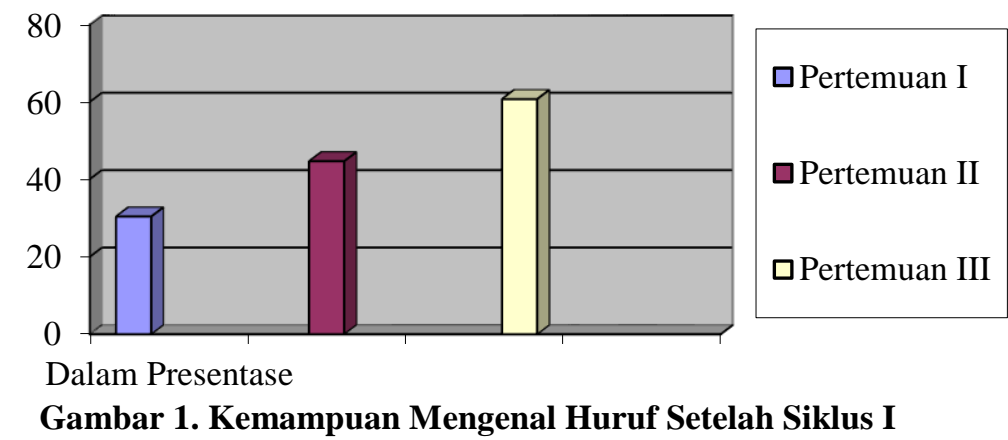

Setelah siklus I dilaksanakan dan dirasa belum memenuhi indikator keberhasilan dilanjutkan ke siklus II. . Hasil pengenalan huruf anak usia 5-6 tahun dengan media kotak pintar pada siklus kedua dapat dilihat melalui tabel berikut ini.

Tabel 4. Hasil Observasi Kemampuan Mengenal Huruf Dalam Kategori Baik Di Siklus II

\begin{tabular}{lccc}
\hline & \multicolumn{3}{c}{ Siklus II } \\
\hline \multirow{2}{*}{ Presentase (\%) } & Pertemuan 1 & Pertemuan 2 & Pertemuan 3 \\
\cline { 2 - 4 } & 76,78 & 85,68 & 92,86 \\
\hline
\end{tabular}

Berdasarkan tabel 2 dapat diketahui tingkat pencapain mengenal huruf di siklus I pada pertemuan pertama menunjukan bahwa $76,78 \%$ anak tergolong pada kategori baik sedangkan pada pertemuan kedua menunjukan $85,68 \%$ anak dalam kategori baik dan pada pertemuan ketiga terdapat $92,86 \%$ anak tergolong dalam kondisi baik. Dalam siklus II ini terdapat tiga kali pertemuan dengan setiap pertemuannya mengalami peningkatan. . Berikut ini gambar peningkatan kemampuan mengenalkan huruf dalam bentuk grafik disetiap pertemuan:

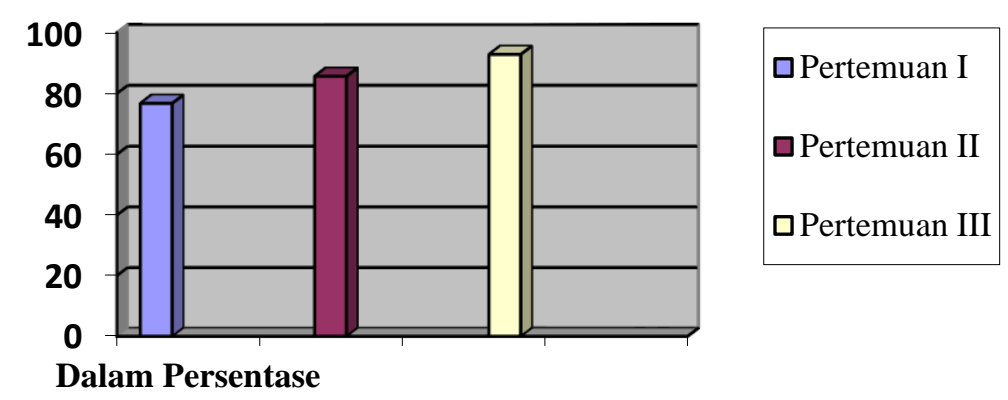

Gambar 2. Kemampuan Mengenal Huruf Setelah Siklus II

Berdasarkan pelaksanaan tindakan yang dilaksanakan dalam 2 siklus menunjukan adanya peningkatan kemampuan mengenal huruf pada kelompok TK B Sion Blora dapat ditegaskan bahwa melalui permainan kotak pintar dapat meningkatkan kemampuan mengenal huruf anak hingga mencapai 90\%. Peningkatan kemampuan mengenal huruf sudah sampai target yang telah ditentukan sehingga pembelajaran diberhentikan sampai siklus II. Peningkatan tersebut dapat dilihat melalui tabel rata-rata ketercapaian kemampuan mengenal huruf setelah siklus II.

Tabel 5. Rata-Rata Ketercapaian Kemampuan Mengenal Huruf Setelah Siklus II

\begin{tabular}{ccc}
\hline \multicolumn{3}{c}{ Rata-rata ketercapaian } \\
\hline Pra Siklus & Siklus I & Siklus II \\
\hline $14,29 \%$ & $60,71 \%$ & $92,86 \%$ \\
\hline
\end{tabular}

Pada tabel 3 tersebut dapat diketahui bahwa, hasil presentase pencapaian mengenal huruf anak usia 5-6 tahun mengalami peningkatan. Pada pra siklus ke siklus I ditunjukan bahwa rata-rata ketercapaian mengalami peningkatan $46,42 \%$ dari $14,29 \%$ menjadi $60,71 \%$. Pada siklus I ke siklus II 
mengalami peningkatan $32,15 \%$ dari $60,71 \%$ menjadi $92,86 \%$. Berikut ini gambar peningkatan kemampuan mengenalkan huruf dalam bentuk grafik disetiap pertemuan:

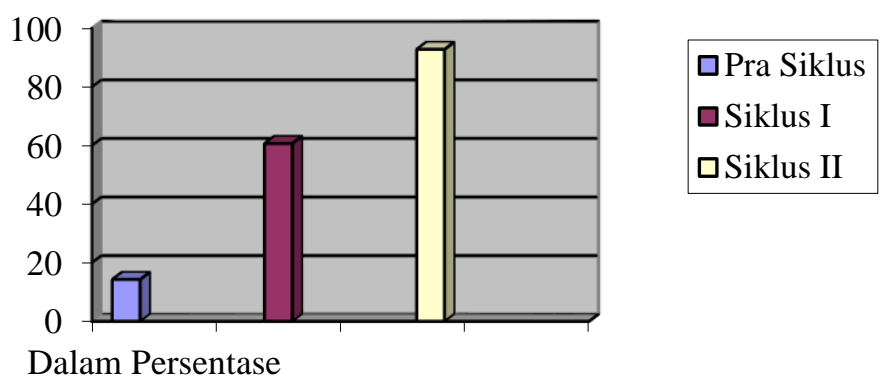

Gambar 3. Rata-Rata Ketercapaian Kemampuan Mengenal Huruf Setelah Siklus II

\section{PEMBAHASAN}

Berdasarkan pelaksanaan tindakan yang dilaksanakan dalam 2 siklus menunjukan adanya peningkatan kemampuan mengenal huruf pada kelompok TK B Sion Blora. Penelitian ini menggunakan teknik analisis deskriptif kuantitatif, sehingga data yang telah terkumpul beruba lembar observasi dihitung secara deskriptif kuantitatif dengan rumus yang telah ditentukan untuk melihat presentase keberhasilan tindakan.

Hasil observasi kemampuan mengenal huruf anak sebelum diadakan tindakan atau pra siklus menunjukan bahwa dari 14 anak yang menjadi subjek penelitian kemampuan mengenal huruf yang meliputi empat indikator menunjukan masih banyak anak yang belum memenuhi di kategori baik dalam kemampuan mengenal huruf. Rata-rata kemampuan mengenal huruf di pra siklus didapatkan 14,29\% dalam kategori baik sedangkan $85,71 \%$ masih memerlukan bantuan.

Hasil observasi kemampuan mengenal huruf anak pada saat pemberian tindakan pertama kalinya anak masih belum mampu mengikuti intruksi yang telah diberikan peneliti sehingga angka presentase keberhasilan yang dicapai setelah diadakan siklus I menunjukan bahwa 30,36\% anak tergolong pada kategori baik sedangkan pada pertemuan kedua menunjukan $44,64 \%$ anak dalam kategori baik dan pada pertemuan ketiga terdapat $60,71 \%$ anak tergolong dalam kondisi baik.

Hasil observasi kemampuan mengenal huruf anak pada siklus yang kedua ini anak-anak sudah mengikuti aturan yang peneliti sampaikan sehingga angka presentase keberhasilan yang dicapai setelah diadakan siklus II menunjukan bahwa 76,78\% anak tergolong pada kategori baik sedangkan pada pertemuan kedua menunjukan $85,68 \%$ anak dalam kategori baik dan pada pertemuan ketiga terdapat $92,86 \%$ anak tergolong dalam kondisi baik.

Hasil tersebut menunjukan terjadinya sebuah peningkatan dari hasil awal atau pra siklus, setelah siklus I dan setelah siklus II. Peningkatan tersebut dapat dilihat melalui tabel rata-rata ketercapaian kemampuan mengenal huruf setelah siklus II. Dalam tindakan ini untuk mencapai hasil yang lebih maksimal diperlukan dukungan antara guru dengan orang tua, menurut (Astuti 2016:264) adanya kerjasama antara guru dan orang tua dapat mengoptimalkan pertumbuhan dan perkembangan anak.

\section{SIMPULAN DAN SARAN}

\section{Simpulan}

Berdasarkan hasil penelitian dan pembahasan yang dilakukan, dapat diambil simpulan bahwa permainan kotak pintar dapat meningkatkan kemampuan mengenal huruf kelompok B di TK Sion Blora. Hal ini dapat dibuktikan berdasarkan presentase yang meningkat dari pra siklus sebesar 14,29\% meningkat sebesar $46,42 \%$ pada siklus I menjadi $60,71 \%$ pada siklus II meningkat sebesar $32,15 \%$ menjadi $92,86 \%$, sehingga pembelajaran dapat dikatakan berhasil karena presentase keberhasilan mencapai $\geq 90 \%$. Peningkatan mengenal huruf ini meliputi anak mampu menunjukan huruf, anak mampu menuliskan beberapa huruf yang membentuk satu kata dengan benar, anak mampu menulisakan namanya dengan benar dan anak mampu mencocokan huruf dengan benar. 
Peningkatan Kemampuan Mengenal Huruf Pada Anak Usia 5-6 Tahun Melalui Metode Bermain

Dengan Media Kotak Pintar (Sheila S. Rahayuningsih, Tritjahjo D. Soesilo, Mozes Kurniawan)

\section{Saran}

Berdasarkan penelitian yang sudah dilakukan, peneliti memberikan saran sebagai berikut.

- Bagi guru: Guru dapat mengembangkan metode dan media yang menarik dan kreatif sehingga anak mampu mengembangkan kemampuannya secara maksimal salah satu metode dan media yang dapat digunakan adalah menggunakan metode bermain dengan media kotak pintar untuk meningkatkan kemampuan mengenal huruf anak usia 5-6 tahun

- Bagi peneliti selanjutnya: Hasil penelitian ini dapat dijadikan referensi untuk penelitian selanjutnya yang terkait dengan peningkatan kemampuan mengenal huruf pada anak usia 5-6 tahun.

\section{DAFTAR PUSTAKA}

Arif, S. Sadiman .2006. Media Pendidikan, Pengertian, Pengembangan Dan Pemanfaatannya. Jakarta: PT Raja Grafindo Persada.

Arikunto, S. 2010. Penelitian Tindakan Kelas. Jakarta: PT Bumi Aksara.

Astuti. A. K. 2016. Pelaksanaan Perilaku Sehat Pada Anak Usia Dini PAUD Purwomukti Desa Batur Kecamatan Getasan. Scholaria: Jurnal Pendidikan Dan Kebudayaan, 6(3), 264-272

Harnanto, S. 2016. Alat Peraga Kotak Belajar Ajaib (Kobela) Dalam Pembelajaran Matematika Materi Perkalian Dan Pembagian Sekolah Dasar.

Kusumawati. D. 2017. Manajemen Sarana Prasarana di Day Care Baby's Home Salatiga. Scholaria: Jurnal Pendidikan Dan Kebudayaan, 7(1), 17-25

Maimunah, H. 2009. PAUD (Pendidikan Anak Usia Dini). Yogyakarta: Diva Press.

Mislahusnika. 2016. Upaya Meningkatkan Kemampuan Mengenal Lambang Huruf Melalui Permainan Pohon Huruf pada Anak Usia Dini di PAUD Teratai. Skripsi (diterbitkan). Bandar Lampung: Fakultas Keguruan dan Ilmu Pendidikan Universitas Lampung.

Otto, Beverly. 2015. Perkembangan Bahasa Pada Anak Usia Dini. Jakarta: Prenadamedia Group.

Peraturan Mentri Pendidikan Dan Kebudayaan Republik Indonesia Nomor 146 Tahun 2014. Jakarta: Departemen Pendidikan Nasional RI.

Puspitasari, K., \& khotimah, M. 2013. Upaya Meningkatkan Kemampuan Mengenal Lambang Bilangan 1-10 Melalui Media Kotak Pintar Pada Anak Kelompok A Tk Pertiwi 1 Balongbesuk Kec. Diwek Kab. Jombang.

Sari, R. Y. 2014. Meningkatkan Keterampilan Membaca Simbol Pada Anak Usia Dini Melalui Permainan Bowling Huruf Di Kelompok A PAUD Bhayangkari 26 Kota Bengkulu. Skripsi (diterbitkan). Bengkulu: Fakultas Keguruan dan Ilmu Pendidikan Universitas Bengkulu.

Soesilo, T. D. 2014. Langka - Langkah Penelitian Tindakan Kelas (Tuntunan Praktis bagi Guru PAUD). Salatiga: Griya Media

Trisnawati. 2014. Peningkatan Kemampuan Mengenal Huruf Melalui Metode Permainan Kartu Huruf Pada Kelompok B1 Tk Aba Ketanggungan Wirobrajan Yogyakarta.

Waraningsih, T. L. 2014. Upaya Meningkatkan Kemampuan Mengenal Huruf Menggunakan Media Kartu Kata Di Tk Sulthoni Ngaglik Sleman.

Zaini, A. 2015. Bermain Sebagai Metode Pembelajaran Bagi Anak Usia Dini. ThufuLA: Jurnal Inovasi Pendidikan Guru Raudhatul Athfal, 3(1). 